\title{
Review
}

\section{Pathobiology of MicroRNAs and Their Emerging Role in Thyroid Fine-Needle Aspiration}

\author{
Marie Ludvíkováa, bavid Kalfeřtc ${ }^{c}$ Ivana Kholovád \\ ${ }^{a}$ Institute of Biology, Faculty of Medicine, Charles University in Prague, Pilsen, ${ }^{b}$ Institute of Pathology, \\ General University Hospital in Prague, Prague, and ${ }^{\mathrm{C}}$ Department of Otorhinolaryngology and Head and \\ Neck Surgery, Faculty of Medicine, University Hospital Hradec Kralove, Charles University in Prague,

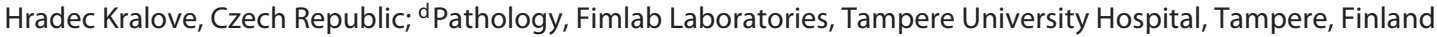

\section{Key Words}

Thyroid $\cdot$ MicroRNA $\cdot$ Molecular analysis

\begin{abstract}
Objective: MicroRNAs (miRs) are noncoding, single-stranded regulatory RNA molecules involved in the posttranscriptional regulation of gene expression. They control the development and maintenance of the diverse cellular processes including proliferation, differentiation, motility and apoptosis. Expression of miRs is tissue-specific and each alteration of the tissue miR profile is associated with a distinct disease status. Study Design: We reviewed the literature on the expression of miRs in thyroid tumors, focusing on methodology and diagnostic and prognostic output. Separately, we analyzed 11 studies on miR profiles in thyroid cytological material. Results: Numerous studies have evaluated the miR profiles of thyroid tumors in an attempt to find a possible diagnostic and prognostic role. Both downregulation and upregulation of numerous miRs was found, but differences between the surgical pathology specimens and corresponding fine-needle aspirates in the expression of the same miRs were also reported. Conclusions: The results from surgically resected material cannot be extrapolated into preoperative
\end{abstract}

use without validation. For diagnostic use, the strong overlap between follicular adenoma and follicular carcinoma miR profiles is challenging. In summary, miR-221 and miR-222 are consistently upregulated in different types of thyroid carcinomas and might be used as markers of malignancy.

(c) 2016 S. Karger AG, Basel

\section{Introduction}

Fine-needle aspiration (FNA) cytology is currently considered the essential preoperative diagnostic method for the evaluation of thyroid nodules. FNA helps to reduce unnecessary surgery for thyroid benign disease. Conventional cytology based on cytomorphology is unable to provide unequivocal diagnosis from all specimens. Such indeterminate cases are usually classified as AUS/ FLUS (atypia of undetermined significance/follicular lesion of undetermined significance) according to the Bethesda System for Reporting Thyroid Cytopathology $[1,2]$. AUS/FLUS account for 3-18\% of thyroid FNA results $[1,3]$. In attempts to avoid surgery for the AUS/ FLUS category and other indeterminate cases, i.e. follicular neoplasms, new thyroid tumor molecular markers

\section{KARGER 125}

C 2016 S. Karger AG, Basel

0001-5547/16/0596-0435\$39.50/0 


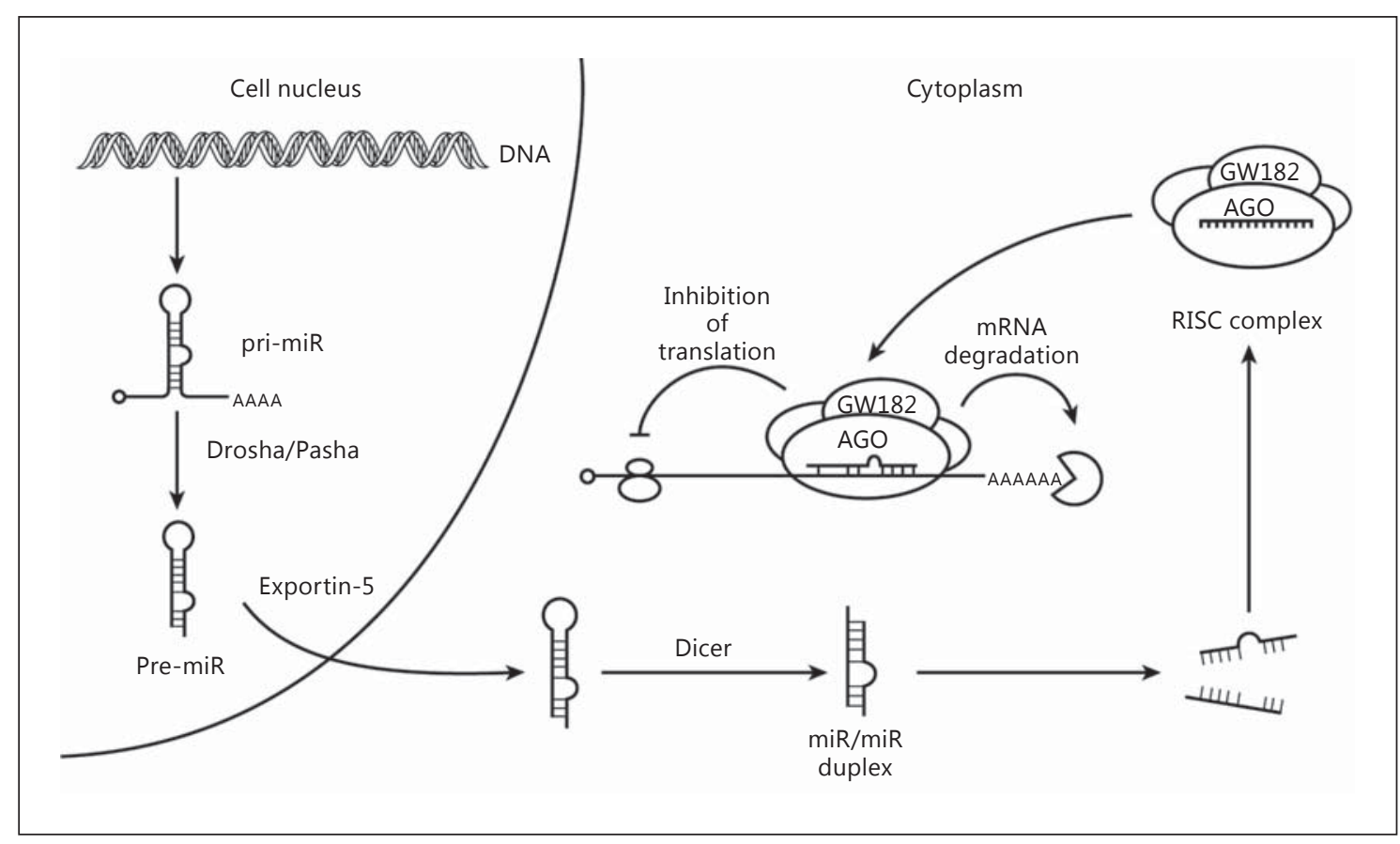

Fig. 1. The mechanisms of miR biogenesis and their function on cellular level.

have been investigated to improve the sensitivity and specificity of FNA cytology [4].

Recent research on thyroid tumors revealed novel diagnostic and prognostic molecular markers reflecting the pathobiology of neoplastic processes as well as novel therapeutic targets. BRAF and RET papillary thyroid carcinoma mutations, in particular, have high specificity in papillary carcinomas [4]. However, the sensitivity of genetic mutational markers is low because about $30-40 \%$ of differentiated thyroid cancers do not have any known mutation $[5,6]$. With the use of a panel of different mutations and chromosomal rearrangements [7], the testing of epigenetic modifications in human thyroid cancer seems to be a promising approach [8]. Epigenetic events were highlighted during the past decade and play an important role in cancer; i.e. the inappropriate regulation of cancerrelated genes. The epigenetic mechanism in carcinogenesis is now emerging as a major player in the interface between genotype to phenotype variability. Epigenetic changes are classified into 3 distinct types: DNA methylation, histone modification and aberrant expression of noncoding RNAs. An abnormal epigenetic pattern in the thyroid gland plays an important role in tumorigenesis by regulating the differentiation and proliferation of transformed thyrocytes [9]. Reversible epigenetic effects (mediated by the enzymes histone deacetylase and methyl- transferase) should be amenable as target drug therapy of thyroid carcinoma in the form of demethylating agents and histone deacetylase inhibitors $[8,10,11]$.

\section{MicroRNAs}

MicroRNAs (miRs) are newly recognized, noncoding, single-stranded regulatory RNA molecules, 18-25 nucleotides in length. MiRs were first discovered in 1993 in Caenorhabditis elegans and this was considered to be a unique event [12]. Contemporary mechanisms of RNA interference, e.g. the silencing of genes by double-stranded RNA was described in 1998 by Fire et al. [13]. Later, it was shown that miRs belong to small RNAs central to RNA interference. Both achievements were awarded with the Nobel Prize in 2006 [14]. Subsequently, the occurrence of miRs in other species has been described [15].

\section{Biogenesis and Function of MicroRNAs}

Canonical miR biogenesis is a multistep process under the control of several enzymes and enzymatic complexes (fig. 1). Briefly, this process starts in the nucleus, where primary $\mathrm{miR}$ (pri-miR) is produced with a long nucleo- 
tide sequence, which contains imperfectly base-paired hairpin structures. During the next step, hairpin-shaped pri-miR enters a complex consisting of the enzyme Drosha and an essential cofactor Pasha to be processed into shorter precursor (pre)-miR and then exported by Exportin-5 to the cytoplasm. Pre-miR is a short-stem loop, 70 nucleotides in length, with a 2 -nucleotide $3{ }^{\prime}$-overhang. At the cytoplasmic level, double-stranded pre-miRs are shortened by the enzymes Dicer and helicase, and, subsequently, this duplex is unwound into 2 single miR strands. The leading strand of the pre-miR is used to produce mature $\mathrm{miR}$, but the second one seems to usually be degraded. The mature miR is incorporated into the RISC (RNAinduced silencing complex) which mediates the interaction between the miR and the target mRNA. The final effect of this interaction is $\mathrm{mRNA}$ cleavage or translational repression (depending on the degree of complementarity between the miR and the $3^{\prime}$ untranslated region of the target mRNA), with simultaneous quick degradation of the $\operatorname{miR}[16]$.

The principal function of miRs is the posttranscriptional regulation of gene expression by the translational repression or degradation of relevant mRNAs. Generally, $\mathrm{miR}$ molecules, having conserved sequences between distantly related organisms, participate in essential, diverse processes ranging from developmental processes to (patho)physiological conditions. MiRs are supposed to control more than one third of the protein-coding genes in the human genome with a broad spectrum of consequences. More than 2,500 mature miRs have been identified in humans (miRBase Sequence Database, Release 21, www.miRBase.org). As much as $40 \%$ of miR genes may be located in the introns of other genes, resulting in the coupled transcription and regulation of the miR gene and its host gene [17]. Not all miR functions are yet fully understood. Each miR can regulate lots of genes downstream by targeting many mRNA transcripts. The dysregulation of miRs has been associated with many specific pathological conditions, including cancer [18].

\section{Detection of MicroRNAs}

MiR profiles have been previously identified in specific tissues of interest using fresh, frozen or formalinfixed paraffin-embedded (FFPE) samples. MiRs stay wellpreserved in FFPE samples, presumably due to their small size. The utility of FFPE tissue is thus comparable with fresh tissue and FFPE samples are appropriate sources for miR expression analyses [19].

MiRs in Thyroid FNA
For both global and specific expression of miRs, many methods have been developed that enable miR microarray profiling or detection of specific miRs. Moreover, $\mathrm{miR}$ functional analysis can be performed with protocols similar to those for standard genes. Briefly, in situ hybridization (ISH) and qRT-PCR miR represent commonly used, fast and cost-effective methods of miR detection. Special next-generation sequencing and microarray methods offer the identification of a broad spectrum of miRs [20].

Besides, it has been recently found that miRs can also be detected in remarkably stable forms in various biological fluids, namely plasma/serum. These circulating miRs are released from cancer cells either passively due to cell injury or actively via the membrane vesicles or protein complexes. The advantage of $\mathrm{miR}$ detection in biological fluid is the convenient, minimally invasive and reproducible approach, making preoperative and postoperative monitoring of $\mathrm{miR}$ profiles possible [21].

\section{MicroRNAs and Cancer}

MiRs are considered to be the important regulators of gene expression on the posttranscriptional level. They control the development and maintenance of diverse cellular processes including proliferation, differentiation, motility and apoptosis [22]. Expression of miRs is tissuespecific and each alteration of $\mathrm{miR}$ profile is associated with a distinct disease status. Owing to the important role of miRs in the regulation of many essential biological processes, their link to cancer is not surprising. The global $\mathrm{miR}$ profile in tumors shows widespread changes at the expression level (upregulation or downregulation) in comparison with normal nonneoplastic tissue. The common deregulation of miR expression in human cancer can be explained by the frequent location of miR genes in chromosomal fragile sites $[23,24]$ as well as by mutations and genetic polymorphisms in miR genes and genes associated with the biogenesis and functions of miRs [25].

Two principal pathogenetic effects of abnormal miR expression (according to the type of target cancer-related genes that are influenced) have been described in the development and progression of human malignancies: the oncogenic and tumor-suppressor effects. The oncogenic mechanism consists of the translation repression of target tumor-suppressor genes by the upregulated specific oncogenic miR, whereas the tumor-suppressor effect is associated with the downregulation of the tumor suppressor miR and subsequent overexpression of target oncogenes. The consequence of both events is an increase in 


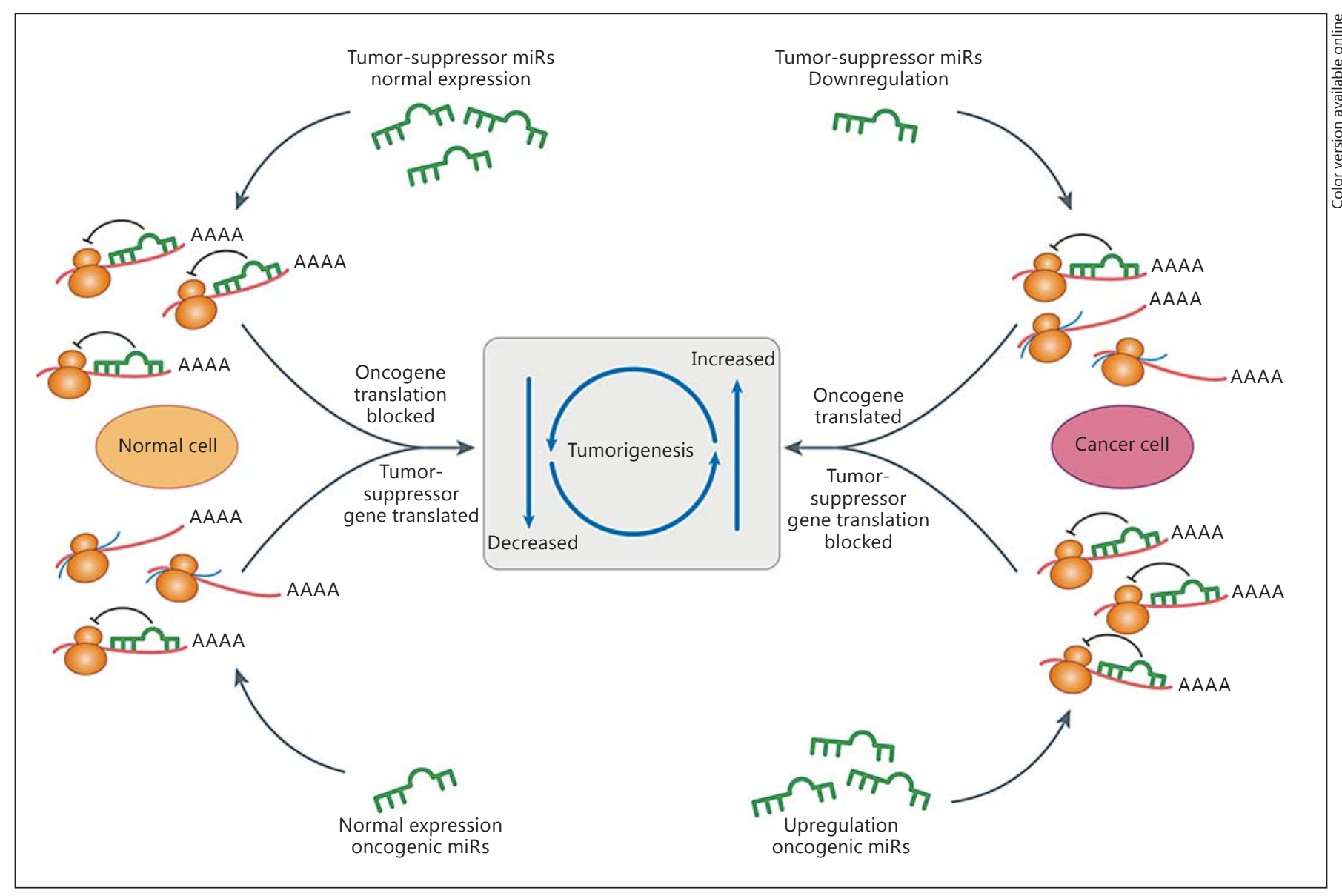

Fig. 2. Role of tumor-suppressor miRs and oncogenic miRs in normal and cancer cells.

tumor-promoting cell proliferation (fig. 2). A dual effect of some miRs, both oncogenic and tumor-suppressing, has also been reported [26].

MiR expression profiles in tumors differ from those in normal tissue and could therefore be important as tumor markers with diagnostic, prognostic and predictive potential $[19,27]$.

\section{MicroRNA Deregulations in Thyroid Tumors}

The thyroid gland is considered to be a suitable model for the study of the role of miR expression patterns in carcinogenesis because thyroid follicular cells can give rise to tumors with distinct biological properties [9]. In addition, morphological diagnosis of thyroid cancer is based on considering specific criteria of malignancy in association with a subjective evaluation. Hence, an interobserver variability in thyroid tumor diagnosis exists, namely in tumors with a follicular growth pattern. The miR profiling of thyroid neoplasms could enable a novel diagnostic approach. Expression of miRs differs in normal and tumor thyroid tissue. Moreover, the miR signature has been shown to correspond with the pathobiology and differentiation of tumors, and so miR expression profiles seem to be specific for different types of thyroid tumors. Significant variability of miR signatures exists, not only between tumors of different histogenesis (e.g. a follicular vs. a Ccell origin) but even among tumors originating from follicular cells [28].

Several studies have evaluated the miR profiles of thyroid carcinomas in attempts to find possible diagnostic and prognostic applications [29, 30]. Generally, miR downregulation is the most common pattern in thyroid cancer cells [28]. As a result, specific miR signatures in distinct histopathological types of thyroid carcinoma have been reported (table 1: summary of selected deregulated miRs). 
Table 1. Selected miR profiles in specific types of thyroid cancer

\begin{tabular}{llllll}
\hline MicroRNA & PTC & FTC & PDTC & ATC & First author, year [ref.] \\
\hline miR-197 & $\uparrow$ & $\uparrow$ & & & Weber, 2006 [31], Nikiforova, 2008 [50] \\
\hline miR-346 & & $\uparrow$ & & & Weber, 2006 [31] \\
\hline miR-146b & $\uparrow$ & $\uparrow$ & $\uparrow$ & $\uparrow$ & Chen, 2008 [35], Dettmer, 2014 [40], Forte, 2015 [28], Yuan, 2014 [29], \\
& & & & & Lee, 2013 [38], Dettmer, 2013 [39], Fuziwara, 2014 [41], Nikiforova, 2008 [50] \\
\hline miR-221 & $\uparrow$ & $\uparrow$ & $\uparrow$ & $\uparrow$ & Chen, 2008 [35], Dettmer, 2014 [40], Lee, 2010 [20], Forte, 2015 [28], \\
\hline miR-222 & $\uparrow$ & $\uparrow$ & $\uparrow$ & $\uparrow$ & Chen, 2008 [35], Dettmer, 2014 [40], Forte, 2015 [28], Yuan, 2014 [29], \\
\hline miR-224 & $\uparrow$ & $\uparrow$ & & $\uparrow$ & Dettmer, 2014 [40], Yuan, 2014 [29] \\
\hline miR-155 & $\uparrow$ & $\uparrow$ & & & Dettmer, 2014 [40], Yuan, 2014 [29] \\
\hline miR-181a & $\uparrow$ & & & & Yuan, 2014 [29] \\
\hline miR-146a & & & & $\uparrow$ & Fuziwara, 2014 [41] \\
\hline miR-30d & & & & $\downarrow$ & Yuan, 2014 [29], Fuziwara, 2014 [41] \\
\hline miR-200 & & & & $\downarrow$ & Yuan, 2014 [29], Fuziwara, 2014 [41] \\
\hline miR-125b & & & & $\downarrow$ & Yuan, 2014 [29] \\
\hline miR-26a & & & & $\downarrow$ & Yuan, 2014 [29] \\
\hline miR-150 & & & $\downarrow$ & & Dettmer, 2014 [40] \\
\hline miR-23b & & & $\downarrow$ & & Dettmer, 2014 [40] \\
\hline miR-187 & $\uparrow$ & & & $\uparrow$ & Forte, 2015 [28], Yip, 2011 [55] \\
\hline
\end{tabular}

ATC = Anaplastic thyroid carcinoma; FTC = follicular thyroid carcinoma PDTC $=$ poorly differentiated thyroid carcinoma; PTC $=$ papillary thyroid carcinoma. $\downarrow=$ Downregulated; $\uparrow=$ upregulated.

Studies that focused on the major types of follicularcell-derived tumors revealed some miR expression differences, with the potential to be useful as diagnostic markers by differentiating between follicular carcinoma and follicular adenoma [31-33]. The principal shortcomings of these studies are the great variability of the miRs studied and the lack of 'consensus miR profiles' from one study to another. Stokowy et al. [34] identified $68 \mathrm{miRs}$ differentially expressed in follicular adenomas and follicular carcinomas but fold changes were small, with only 2 miRs (miR-137 and miR-767-5p) showing higher than 2-fold upregulation and 4 miRs (miR-7-5p, miR-7-2-3p, miR-1179 and miR-144-5p) revealing more than 2 -fold downregulation in follicular carcinomas. Moreover, many studies have shown a strong overlap of miR profiles in follicular adenoma and follicular carcinoma as well as in papillary carcinomas and follicular tumors [35-37]. One possible explanation of the overlapping of deregulated miRs among different groups of thyroid tumors may lie in the morphological diagnostic pitfalls of thyroid tumors or in the different methods of miR analysis. Interestingly, changes in miR expression occur predominantly during the transition from normal thyrocytes into follicular adenoma cells rather than between the change-over from follicular adenoma to follicular carcinoma [36].
MiR-221, miR-222 and miR-146b are considered to be markers of papillary carcinoma, although overexpression of miR-221 and miR-222 in follicular adenomas and carcinomas compared with normal thyroid tissue has also been reported. In addition, upregulated miR-146b has been found in nonpapillary carcinomas [35,37]. Notably, the same dynamics of plasma miR-222 and miR-146b expression were described in patients with papillary carcinoma and multinodular goiter [38].

In the follicular variant of papillary carcinoma, several miRs are downregulated in the same pattern as in classic papillary carcinoma, i.e. miR-1179, miR-138, miR-1445p, miR-199b-5p, miR-204, miR-219-5p and miR-451. Two novel miRs, miR-375 and miR-551b, are highly upregulated in this variant [39].

Recently, miR885-5p was demonstrated to be significantly upregulated in oncocytic follicular carcinomas in comparison with conventional ones. In this instance, miR-885-5p possibly plays a role in oncocytic tumor mitochondria accumulation. In addition, poorly differentiated oncocytic carcinomas show miR-221 and miR-885$5 p$ upregulation $[37,39,40]$.

Poorly differentiated carcinomas can be separated from well-differentiated carcinomas with $73-79 \%$ accuracy by miR-23b and miR-150, with both of these miRs 
Table 2. Selected single miRs in thyroid FNA samples

\begin{tabular}{llll}
\hline MiR & & $\begin{array}{l}\text { Diagnostic conclusion } \\
\text { (included FFPE tissue studies) }\end{array}$ & $\begin{array}{l}\text { First author, year [ref.] } \\
\text { (FNA studies) }\end{array}$ \\
\hline miR-146b & $\uparrow$ & PTC & $\begin{array}{l}\text { Mazeh, 2013 [45], Agretti, 2012 [46], Chen, 2008 [35], } \\
\text { Shen, 2012 [47], Nikiforova, 2008 [50], Mazeh, 2011 [51] }\end{array}$ \\
\hline miR-187 & $\uparrow$ & PTC, FTC, ATC & Mazeh, 2013 [45], Shen, 2012 [47] \\
\hline miR-221 & $\uparrow$ & PTC, FTC, ATC & $\begin{array}{l}\text { Mazeh, 2013 [45], Agretti, 2012 [46], Dettmer, 2014 [40], } \\
\text { Shen, 2012 [47], Mazeh, 2011 [51] }\end{array}$ \\
\hline miR-138 & $\downarrow$ & FTC & Vriens, 2012 [32] \\
\hline miR-21 & $\uparrow$ & PTC & Mazeh, 2013 [45], Keutgen, 2012 [48] \\
\hline miR-222 & $\uparrow$ & PTC, FTC, ATC & $\begin{array}{l}\text { Mazeh, 2013 [45], Chen, 2008 [35], Keutgen, 2012 [48], } \\
\text { Nikiforova, 2008 [50], Mazeh, 2011 [51] }\end{array}$ \\
\hline
\end{tabular}

ATC = Anaplastic thyroid carcinoma; FTC $=$ follicular thyroid carcinoma; PDTC $=$ poorly differentiated thyroid carcinoma; PTC $=$ papillary thyroid carcinoma. $\downarrow=$ Downregulated; $\uparrow=$ upregulated.

having prognostic potential [40]. The pathobiology of anaplastic thyroid cancer (ATC) is associated with the downregulation of many miRs in contrast to other thyroid carcinomas of follicular cell origin [29]. Some ATC cases indicate the early event in thyroid carcinogenesis being abnormally regulated as far back as in differentiated thyroid cancer (e.g. upregulated miR-146b, miR221 and miR-222). Specific group of miRs with an impact on the process of aggressiveness (the miR-200 and miR30 families) are downregulated only in ATC [41]. Hebrant et al. [42] revealed 17 miRs that are significantly downregulated uniquely in ATC, and described their role in regulating the epithelial to mesenchymal transition. In borderline tumors, which are often diagnostically challenging [43], no specific miR profile has been defined $[35,44]$.

To summarize, the most commonly studied miRs are presented in table 2. Among them, miR- 221 and miR-222 are the most commonly reported upregulated miRs in thyroid carcinoma [35, 40, 45-48].

\section{MicroRNAs in Thyroid Fine-Needle Aspirations}

In thyroid tumors, miR expression profiles have also been analyzed in cells from FNA samples. Eleven studies on thyroid miR profiling from cytological samples are summarized in table 3. Methodologically, snap-frozen FNA material was the most commonly used, followed by needle-leftovers and scraped cells [32, 35, 37, 45-52]. Petriella et al. [53] found comparable results for miR profiles in Thin-Prep FNA and tissue-based samples of non- small-cell lung cancer. Alarmingly, differences between the surgical pathology specimens and corresponding thyroid FNA samples in the expression of the same miRs were also detected [33, 35, 37].

RT-PCR was the method of choice for the FNA studies. Some of the studies included training and validation series [46-49]. The series included $<100$ samples, with the exception of the study by Vriens et al. [32], with 125 cases.

Ten studies were able to distinguish benign from malignant nodules [32, 35, 37, 45-51]; however, in some, the malignancy was limited only to papillary carcinomas $[35$, 45-47]. MiR detection in FNA biopsy material is feasible for the preoperative detection of papillary carcinoma with the miR-146b, miR-221 and miR-222 panel.

Low accuracy for follicular neoplasms was shown in some of the studies [47]; however, in 1 study [45], 50\% of patients with follicular neoplasms could be treated differently when using miR preoperative analysis. Of 4 studies that focused on indeterminate cytology samples [32, 46, 48,49 ], 3 were able to distinguish benign from malignant nodules [32, 48, 49], but the study by Agretti et al. [46] was limited to distinguishing benign nodules from papillary carcinomas.

The predictive performance dramatically increased to $100 \%$ sensitivity, $95 \%$ specificity and $97 \%$ accuracy when oncocytic lesions were excluded from the analysis [48]. Oncocytic lesions seem to be problematic with other markers too [54]. On the other hand, Dettmer et al. [37] found a set of miRs that were overexpressed in both conventional and oncocytic follicular carcinomas (6- to 9-fold and 10- to 30-fold, respectively). 
Table 3. Summary of studied miR sets in thyroid FNA

\begin{tabular}{|c|c|c|c|c|c|c|c|c|c|c|c|}
\hline MiR set & Sample size, $\mathrm{n}$ & Material & $\begin{array}{l}\text { Detection } \\
\text { technique }\end{array}$ & Control & Sensitivity & Specificity & PPV & NPV & Accuracy & Conclusion & Reference \\
\hline $\begin{array}{l}146 \mathrm{~b}, 221 \\
187,30 \mathrm{~d}\end{array}$ & $\begin{array}{l}60 \text { training samples } \\
68 \text { validation samples } \\
30 \text { validation atypia } \\
\text { samples }\end{array}$ & $\begin{array}{l}\text { cells scraped } \\
\text { from slides with } \\
\text { a razor blade }\end{array}$ & RT-PCR & n.d. & $\begin{array}{l}93.2 \\
88.9 \\
63.6\end{array}$ & $\begin{array}{l}93.8 \\
78.3 \\
78.9\end{array}$ & $\begin{array}{l}0.98 \\
0.89 \\
0.64\end{array}$ & $\begin{array}{l}0.83 \\
0.78 \\
0.79\end{array}$ & $\begin{array}{l}93.3 \\
85.3 \\
73.3\end{array}$ & $\begin{array}{l}\text { feasible to identify } \\
\text { papillary carcinomas, } \\
\text { low accuracy for } \\
\text { follicular neoplasms }\end{array}$ & $\begin{array}{l}\text { Shen, } \\
2012 \text { [47] }\end{array}$ \\
\hline $\begin{array}{l}21,31, \\
146 b, 187 \\
221,222 \\
\end{array}$ & $\begin{array}{l}77 \\
12 \text { indeterminate } \\
\text { cytology }\end{array}$ & $\begin{array}{l}\text { cell leftovers } \\
\text { in FNAB needle }\end{array}$ & RT-PCR & $\begin{array}{l}\text { normal } \\
\text { thyroid } \\
\text { gland }\end{array}$ & 88 & 100 & 100 & 66 & 90 & $\begin{array}{l}\text { change treatment in } \\
50 \% \text { of patients with } \\
\text { follicular neoplasm }\end{array}$ & $\begin{array}{l}\text { Mazeh, } \\
2013[45]\end{array}$ \\
\hline $\begin{array}{l}100,125 b \\
138,768-3 p\end{array}$ & $\begin{array}{l}125 \text { indeterminate } \\
\text { cytology }\end{array}$ & $\begin{array}{l}\text { snap-frozen, } \\
\text { extra passes/ } \\
\text { residual material }\end{array}$ & qRT-PCR & n.d. & n.d. & n.d. & n.d. & n.d. & 79 & $\begin{array}{l}\text { can help distinguish } \\
\text { benign from } \\
\text { malignant on } \\
\text { indeterminate cytology }\end{array}$ & $\begin{array}{l}\text { Vriens, } \\
2012[32]\end{array}$ \\
\hline $\begin{array}{l}222,328 \\
197,21\end{array}$ & $\begin{array}{l}29 \text { training samples } \\
72 \text { validation } \\
\text { indeterminate } \\
\text { cytology samples }\end{array}$ & $\begin{array}{l}\text { ex vivo } \\
\text { snap-frozen }\end{array}$ & RT-PCR & & 100 & 86 & n.d. & n.d. & 90 & $\begin{array}{l}\text { useful adjunct tool } \\
\text { to distinguish } \\
\text { indeterminate benign } \\
\text { from malignant }\end{array}$ & $\begin{array}{l}\text { Keutgen, } \\
2012[48]\end{array}$ \\
\hline 146b, 222 & 40 & $\begin{array}{l}\text { ex vivo, } \\
\text { snap-frozen }\end{array}$ & qRT-PCR & $\begin{array}{l}\text { follicular } \\
\text { adenomas, } \\
\text { hyper- } \\
\text { plastic } \\
\text { nodules }\end{array}$ & n.d. & n.d. & n.d. & n.d. & n.d. & $\begin{array}{l}\text { adjunct marker to } \\
\text { diagnose papillary } \\
\text { carcinoma on FNA }\end{array}$ & $\begin{array}{l}\text { Chen, } \\
2008[35]\end{array}$ \\
\hline $\begin{array}{l}885-5 p \\
221,574-3 p\end{array}$ & 19 & snap-frozen & $\begin{array}{l}\text { TaqMan } \\
\text { human } \\
\text { microarray } \\
\text { assay }\end{array}$ & $\begin{array}{l}\text { normal } \\
\text { thyroid } \\
\text { tissue }\end{array}$ & n.d. & n.d. & n.d. & n.d. & 100 & $\begin{array}{l}100 \% \text { accuracy to } \\
\text { distinguish benign } \\
\text { from malignant } \\
\text { on FNA }\end{array}$ & $\begin{array}{l}\text { Dettmer, } \\
2013[37]\end{array}$ \\
\hline 7,126 & $\begin{array}{l}95 \text { training samples } \\
59 \text { validation samples }\end{array}$ & $\begin{array}{l}\text { snap-frozen } \\
\text { snap-frozen }\end{array}$ & qRT-PCR & n.d. & $\begin{array}{l}82 \\
100\end{array}$ & $\begin{array}{l}73 \\
29\end{array}$ & $\begin{array}{l}56 \\
36\end{array}$ & $\begin{array}{l}91 \\
100\end{array}$ & $\begin{array}{l}76 \\
76\end{array}$ & $\begin{array}{l}\text { distinguishes } \\
\text { indeterminate } \\
\text { benign from } \\
\text { malignant samples }\end{array}$ & $\begin{array}{l}\text { Kitano, } \\
2012[49]\end{array}$ \\
\hline $\begin{array}{l}146 \mathrm{~b}, 155 \\
221\end{array}$ & $\begin{array}{l}87 \text { training samples } \\
53 \text { validation samples }\end{array}$ & $\begin{array}{l}\text { cell leftovers } \\
\text { in FNAB needle }\end{array}$ & RT-PCR & $\begin{array}{l}\text { normal } \\
\text { thyroid } \\
\text { tissue }\end{array}$ & $\begin{array}{l}97.67 \\
79.07\end{array}$ & $\begin{array}{l}97.77 \\
77.77\end{array}$ & $\begin{array}{l}\text { n.d. } \\
\text { n.d. }\end{array}$ & $\begin{array}{l}\text { n.d. } \\
\text { n.d. }\end{array}$ & $\begin{array}{l}97.73 \\
78.41\end{array}$ & $\begin{array}{l}\text { discriminates benign } \\
\text { nodules from } \\
\text { papillary carcinomas } \\
\text { on FNA, but limited } \\
\text { for indeterminate } \\
\text { nodules }\end{array}$ & $\begin{array}{l}\text { Agretti, } \\
2012[46]\end{array}$ \\
\hline $\begin{array}{l}222,146 \mathrm{~b}, \\
155,224, \\
197\end{array}$ & 62 & snap-frozen & RT-PCR & $\begin{array}{l}\text { normal } \\
\text { thyroid } \\
\text { tissue }\end{array}$ & n.d. & n.d. & n.d. & n.d. & n.d. & $\begin{array}{l}\text { set of miR can detect } \\
\text { thyroid carcinomas } \\
\text { on FNA }\end{array}$ & $\begin{array}{l}\text { Nikiforova, } \\
2008[50]\end{array}$ \\
\hline $\begin{array}{l}21,31 \\
146 b, 187 \\
221,222\end{array}$ & 27 & $\begin{array}{l}\text { FNAB from } \\
\text { surgical specimen }\end{array}$ & qRT-PCR & $\begin{array}{l}\text { contra- } \\
\text { lateral } \\
\text { thyroid } \\
\text { lobe }\end{array}$ & 100 & 96 & 100 & 98 & $\begin{array}{l}\text { 92-98 } \\
\text { (counted } \\
\text { for separate } \\
\text { miRs) }\end{array}$ & $\begin{array}{l}\text { miRs can improve } \\
\text { diagnostic accuracy } \\
\text { of FNA }\end{array}$ & $\begin{array}{l}\text { Mazeh, } \\
2011[51]\end{array}$ \\
\hline $\begin{array}{l}26 a, 146 b, \\
221,222\end{array}$ & 57 & $\begin{array}{l}\text { scraped cells from } \\
\text { cytology slides }\end{array}$ & qRT-PCR & n.d. & 80 & 90 & n.d. & n.d. & n.d. & $\begin{array}{l}\text { diagnostic set for } \\
\text { ATC }\end{array}$ & $\begin{array}{l}\text { Fassina, } \\
2014[52]\end{array}$ \\
\hline
\end{tabular}

n.d. = Not determined; NPV = negative predictive value; PPV = positive predictive value.

A panel of 4 upregulated miRs (miR-26a, miR-146b, miR-221 and miR-222) was studied on thyroid cytology smears to distinguish ATCs from lymphomas [52].

\section{Prognostic MiRs}

The second aspect of miR profiling in thyroid tumors is its prognostic, and, consequently, predictive role. However, only sporadic studies have so far focused on the association between miR deregulation and thyroid cancer prognosis and therapy [40, 55-59].

Aggressive BRAF-positive papillary carcinomas are associated with overexpression of miR-146b. Notably,
miRs are independent of BRAF mutational status and may be used as risk stratification markers in BRAF-positive cases [55]. In addition to miR-146b, miR-221 and miR-222 are associated with extrathyroidal invasion [60]. The prognostic role of MiR-146b has been confirmed in other studies $[38,56]$. MiR-146b reveals aggressive features, not only in thyroid papillary cancer but also in other malignancies [56]. Therapeutic inhibition of miR-146b in dedifferentiated thyroid carcinoma represents a promising way to enhance radioiodine uptake and the efficacy of radioactive therapy [57]. However, Sondermann et al. [59] found no significant differences in miR-146b expression between recurrent and nonrecurrent papillary carcinomas. 
Upregulation of miR-146b, miR-221, miR-222, miR155 and miR-31 and downregulation of miR-1, miR-34b, miR-130b and miR-138 were correlated with aggressive papillary carcinomas [55]. Recently, miR-9 and miR-21 were suggested to be valuable prognosticators for thyroid papillary carcinoma recurrence [59]. On the other hand, the upregulation of miR-181a-2-3p and miR-99b-3p and the downregulation of miR-222 have been associated with a favorable outcome in the follicular variant of papillary carcinoma [39].

MiR-30a downregulation is associated with advanced, well-differentiated carcinomas and higher mortality as well as metastatic potential. MiR-30a is upregulated in ATC [61].

MiR-100 expression correlates with TNM staging status, with significantly different expression in $\mathrm{T}_{1}$ and $\mathrm{T}_{4}$ tumors [32].

Some circulating miRs have been reported as prognostic markers in thyroid tumors $[38,62]$. In contrast to tissue analysis, no differences in plasma miR-222 and miR$146 \mathrm{~b}$ were described between patients with papillary thyroid carcinoma and multinodular goiter [42]. The potential principal role of circulating miR biomarkers seems to be in the monitoring of the dynamics of thyroid cancer. However, the tissue miR expression profile has been reported to be more reliable in the detection and staging of cancer because the mechanism of release of miRs into the blood is not clear and cell death and tumorderived microvesicles represent the main source of miRs [62].

Meta-analyses have shown that miR panels can improve FNA diagnostic accuracy to differentiate benign from malignant nodules $[63,64]$, but a discrepancy between miR profiles in surgically resected tissues and FNA material was also found in several studies [33, 35, 37]. In view of these findings, the results from surgically resected material cannot be extrapolated into preoperative use without further validation.

\section{Conclusions}

In diagnostic use, the strong overlap of miR profiles between follicular adenoma and follicular carcinoma presents a challenge. In summary, miR-221 and miR-222 are consistently upregulated in different types of thyroid carcinomas and might be used as markers of malignancy.

Nevertheless, more studies of miRs are required in thyroid tumors to establish their diagnostic, prognostic and predictive role in clinical practice. Many limitations exist, involving the plentiful and commonly antagonistic functions of distinct miRs both in neoplasms with the same site of origin and in tumors at different locations.

In conclusion, the identification of miRs and their putative target genes puts the therapeutic in perspective, in terms of small molecular inhibitors, kinase inhibitors, gene therapies, especially in tumors with a poor prognosis.

\section{Acknowledgements}

M.L. and D.K. were supported by the Charles University Research Fund (project PRVOUK No. P36). I.K. was supported by EVO grants from the Pirkanmaa Hospital District and the Emil Aaltonen Foundation.

\section{References}

1 Cibas ES, Ali SZ: The Bethesda System for Reporting Thyroid Cytopathology. Am J Clin Pathol 2009;132:658-665.

2 Kholová I, Ludvíková M: Thyroid atypia of undetermined significance or follicular lesion of undetermined significance: an indispensable Bethesda 2010 diagnostic category or waste garbage? Acta Cytol 2014;58:319-329.

-3 Bongiovanni M, Krane JF, Cibas ES, Faquin WC: The atypical thyroid fine-needle aspiration: past, present, and future. Cancer Cytopathol 2012;120:73-86.

4 Nikiforov YE, Nikiforova MN: Molecular genetics and diagnosis of thyroid cancer. Nat Rev Endocrinol 2011;7:569-580.

5 Gilfillan CP: Review of the genetics of thyroid tumours: diagnostic and prognostic implications. ANZ J Surg 2010;80:33-40.
6 Xing M, Haugen BR, Schlumberger M: Progress in molecular-based management of differentiated thyroid cancer. Lancet 2013;381: 1058-1069.

7 Nikiforov YE, Steward DL, Robinson-Smith TM, Haugen BR, Klopper JP, Zhu Z, Fagin JA, Falciglia M, Weber K, Nikiforova MN: Molecular testing for mutations in improving the fine-needle aspiration diagnosis of thyroid nodules. J Clin Endocrinol Metab 2009;94: 2092-2098.

8 Catalano MG, Fortunati N, Boccuzzi G: Epigenetics modifications and therapeutic prospects in human thyroid cancer. Front Endocrinol (Lausanne) 2012;3:40.

-9 Faam B, Ghaffari MA, Ghadiri A, Azizi F: Epigenetic modifications in human thyroid cancer. Biomed Rep 2015;3:3-8.
10 Russo D, Damante G, Puxeddu E, Durante C, Filetti S: Epigenetics of thyroid cancer and novel therapeutic targets. J Mol Endocrinol 2011;46:R73-R81.

11 Vu-Phan D, Koenig RJ: Genetics and epigenetics of sporadic thyroid cancer. Mol Cell Endocrinol 2014;386:55-66.

12 Lee RC, Feinbaum RL, Ambros V: The C. ele gans heterochronic gene lin- 4 encodes small RNAs with antisense complementarity to lin14. Cell 1993;75:843-854.

13 Fire A, Xu S, Montgomery MK, Kostas SA, Driver SE, Mello CC: Potent and specific genetic interference by double-stranded RNA in Caenorhabditis elegans. Nature 1998;391: 806-811. 
14 Zhou X, Yang PC: MicroRNA: a small molecule with a big biological impact. MicroRNA 2012;1:1.

-15 Tuschl T, Zamore PD, Lehmann R, Bartel DP, Sharp PA: Targeted mRNA degradation by double-stranded RNA in vitro. Genes Dev 1999;13:3191-3197.

16 Ross JS, Carlson JA, Brock G: MiRNA: the new gene silencer. Am J Clin Pathol 2007;128: 830-836.

17 Rodriguez A, Griffiths-Jones S, Ashurst JL, Bradley A: Identification of mammalian microRNA host genes and transcription units. Genome Res 2004;14:1902-1910.

$\checkmark 18$ Kalfert D, Pesta M, Kulda V, Topolcan O, Ryska A, Celakovsky P, Laco J, Ludvikova M: MicroRNA profile in site-specific head and neck squamous cell cancer. Anticancer Res 2015;35:2455-2463.

-19 Lu J, Getz G, Miska EA, Alvarez-Saavedra E, Lamb J, Peck D, Sweet-Cordero A, Ebert BL, Mak RH, Ferrando AA, Downing JR, Jacks T, Horvitz HR, Golub TR: MicroRNA expression profiles classify human cancers. Nature 2005;435:834-838.

20 Lee LW, Zhang S, Etheridge A, Ma L, Martin D, Galas D, Wang K: Complexity of the microRNA repertoire revealed by next-generation sequencing. RNA 2010;16:2170-2180.

21 Cheng G: Circulating miRNAs: roles in cancer diagnosis, prognosis and therapy. Adv Drug Deliv Rev 2015;81:75-93.

22 Bartel DP: MicroRNAs: genomics, biogenesis, mechanism, and function. Cell 2004;116: 281-297.

-23 Calin GA, Sevignani C, Dumitru CD, Hyslop T, Noch E, Yendamuri S, Shimizu M, Rattan S, Bullrich F, Negrini M, Croce CM: Human microRNA genes are frequently located at fragile sites and genomic regions involved in cancers. Proc Natl Acad Sci USA 2004;101: 2999-3004

24 Marini F, Luzi E, Brandi ML: MicroRNA role in thyroid cancer development. J Thyroid Res 2011;2011:407123.

25 Ryan BM, Robles AI, Harris CC: Genetic variation in microRNA networks: the implications for cancer research. Nat Rev Cancer 2010;10:389-402.

-26 Fabbri M, Ivan M, Cimmino A, Negrini M, Calin GA: Regulatory mechanisms of microRNA involvement in cancer. Expert Opin Biol Ther 2007;7:1009-1019.

-27 Negrini M, Ferracin M, Sabbioni S, Croce CM: MicroRNAs in human cancer: from research to therapy. J Cell Sci 2007;120:18331840.

28 Forte S, La Rosa C, Pecce V, Rosignolo F, Memeo L: The role of microRNAs in thyroid carcinomas. Anticancer Res 2015;35:20372047.

29 Yuan ZM, Yang ZL, Zheng Q: Deregulation of microRNA expression in thyroid tumors. J Zhejiang Univ Sci B 2014;15:212-224.

- 30 Leonardi GC, Candido S, Carbone M, Colaianni V, Garozzo SF, Cina D, Libra M: MicroRNAs and thyroid cancer: biological and clinical significance (review). Int J Mol Med 2012;30:991-999.

-31 Weber F, Teresi RE, Broelsch CE, Frilling A, Eng C: A limited set of human microRNA is deregulated in follicular thyroid carcinoma. J Clin Endocrinol Metab 2006;91:3584-3591.

- 32 Vriens MR, Weng J, Suh I, Huynh N, Guerrero MA, Shen WT, Duh QY, Clark OH, Kebebew E: MicroRNA expression profiling is a potential diagnostic tool for thyroid cancer. Cancer 2012;118:3426-3432.

33 Kitano M, Rahbari R, Patterson EE, Xiong Y, Prasad NB, Wang Y, Zeiger MA, Kebebew E: Expression profiling of difficult-to-diagnose thyroid histologic subtypes shows distinct expression profiles and identify candidate diagnostic microRNAs. Ann Surg Oncol 2011;18: 3443-3452.

34 Stokowy T, Wojtas B, Krajewska J, Stobiecka E, Dralle H, Musholt T, Hauptmann S, Lange D, Hegedus L, Jarzab B, Krohn K, Paschke R, Eszlinger M: A two miRNA classifier differentiates follicular thyroid carcinomas from follicular thyroid adenomas. Mol Cell Endocrinol 2015;399:43-49.

35 Chen YT, Kitabayashi N, Zhou XK, Fahey TJ 3rd, Scognamiglio T: MicroRNA analysis as a potential diagnostic tool for papillary thyroid carcinoma. Mod Pathol 2008;21:1139-1146.

36 Rossing M, Borup R, Henao R, Winther O, Vikesaa J, Niazi O, Godballe C, Krogdahl A, Glud M, Hjort-Sorensen C, Kiss K, Bennedbaek FN, Nielsen FC: Down-regulation of microRNAs controlling tumourigenic factors in follicular thyroid carcinoma. J Mol Endocrinol 2012;48:11-23.

37 Dettmer M, Vogetseder A, Durso MB, Moch H, Komminoth P, Perren A, Nikiforov YE, Nikiforova MN: MicroRNA expression array identifies novel diagnostic markers for conventional and oncocytic follicular thyroid carcinomas. J Clin Endocrinol Metab 2013; 98:E1-E7.

38 Lee JC, Zhao JT, Clifton-Bligh RJ, Gill A, Gundara JS, Ip JC, Glover A, Sywak MS, Delbridge LW, Robinson BG, Sidhu SB: MicroRNA-222 and microRNA-146b are tissue and circulating biomarkers of recurrent papillary thyroid cancer. Cancer 2013;119:43584365.

39 Dettmer M, Perren A, Moch H, Komminoth P, Nikiforov YE, Nikiforova MN: Comprehensive microRNA expression profiling identifies novel markers in follicular variant of papillary thyroid carcinoma. Thyroid 2013; 23:1383-1389.

40 Dettmer MS, Perren A, Moch H, Komminoth P, Nikiforov YE, Nikiforova MN: MicroRNA profile of poorly differentiated thyroid carcinomas: new diagnostic and prognostic insights. J Mol Endocrinol 2014;52:181-189.

41 Fuziwara CS, Kimura ET: MicroRNA deregulation in anaplastic thyroid cancer biology. Int J Endocrinol 2014;2014:743450.

42 Hebrant A, Floor S, Saiselet M, Antoniou A, Desbuleux A, Snyers B, La C, de Saint Aubain N, Leteurtre E, Andry G, Maenhaut C: Mi-
RNA expression in anaplastic thyroid carcinomas. PLoS One 2014;9:e103871.

43 Williams ED: Guest editorial: two proposals regarding the terminology of thyroid tumors. Int J Surg Pathol 2000;8:181-183.

44 Lassalle S, Hofman V, Ilie M, Bonnetaud C, Puissegur MP, Brest P, Loubatier C, Guevara $\mathrm{N}$, Bordone O, Cardinaud B, Lebrigand $\mathrm{K}$, Rios G, Santini J, Franc B, Mari B, Al Ghuzlan A, Vielh P, Barbry P, Hofman P: Can the microRNA signature distinguish between thyroid tumors of uncertain malignant potential and other well-differentiated tumors of the thyroid gland? Endocr Relat Cancer 2011;18: 579-594.

45 Mazeh H, Levy Y, Mizrahi I, Appelbaum L, Ilyayev N, Halle D, Freund HR, Nissan A: Differentiating benign from malignant thyroid nodules using micro ribonucleic acid amplification in residual cells obtained by fine needle aspiration biopsy. J Surg Res 2013;180:216221.

46 Agretti P, Ferrarini E, Rago T, Candelieri A, De Marco G, Dimida A, Niccolai F, Molinaro A, Di Coscio G, Pinchera A, Vitti P, Tonacchera M: MicroRNA expression profile helps to distinguish benign nodules from papillary thyroid carcinomas starting from cells of fineneedle aspiration. Eur J Endocrinol 2012;167: 393-400.

47 Shen R, Liyanarachchi S, Li W, Wakely PE Jr, Saji M, Huang J, Nagy R, Farrell T, Ringel MD, de la Chapelle A, Kloos RT, He H: MicroRNA signature in thyroid fine needle aspiration cytology applied to 'atypia of undetermined significance' cases. Thyroid 2012;22: 9-16.

48 Keutgen XM, Filicori F, Crowley MJ, Wang Y, Scognamiglio T, Hoda R, Buitrago D, Cooper $\mathrm{D}$, Zeiger MA, Zarnegar R, Elemento O, Fahey TJ 3rd: A panel of four miRNAs accurately differentiates malignant from benign indeterminate thyroid lesions on fine needle aspiration. Clin Cancer Res 2012;18:2032-2038.

49 Kitano M, Rahbari R, Patterson EE, Steinberg SM, Prasad NB, Wang Y, Zeiger MA, Kebebew E: Evaluation of candidate diagnostic microRNAs in thyroid fine-needle aspiration biopsy samples. Thyroid 2012;22:285-291.

-50 Nikiforova MN, Tseng GC, Steward D, Diorio D, Nikiforov YE: MicroRNA expression profiling of thyroid tumors: biological significance and diagnostic utility. J Clin Endocrinol Metab 2008;93:1600-1608.

51 Mazeh H, Mizrahi I, Halle D, Ilyayev N, Stojadinovic A, Trink B, Mitrani-Rosenbaum S, Roistacher M, Ariel I, Eid A, Freund HR, Nissan A: Development of a microRNA-based molecular assay for the detection of papillary thyroid carcinoma in aspiration biopsy samples. Thyroid 2011;21:111-118.

52 Fassina A, Cappellesso R, Simonato F, Siri M, Ventura L, Tosato F, Busund LT, Pelizzo MR, Fassan M: A 4-microRNA signature can discriminate primary lymphomas from anaplastic carcinomas in thyroid cytology smears. Cancer Cytopathol 2014;122:274-281. 
53 Petriella D, Galetta D, Rubini V, Savino E, Paradiso A, Simone G, Tommasi S: Molecular profiling of Thin-Prep FNA samples in assisting clinical management of non-small-cell lung cancer. Mol Biotechnol 2013;54:913919.

54 Kholová I, Ryska A, Ludvíková M, Cáp J, Pecen L: Dipeptidyl peptidase IV expression in thyroid cytology: retrospective histologically confirmed study. Cytopathology 2003;14:2731.

55 Yip L, Kelly L, Shuai Y, Armstrong MJ, Nikiforov YE, Carty SE, Nikiforova MN: MicroRNA signature distinguishes the degree of aggressiveness of papillary thyroid carcinoma. Ann Surg Oncol 2011;18:2035-2041.

56 Chou CK, Yang KD, Chou FF, Huang CC, Lan YW, Lee YF, Kang HY, Liu RT: Prognostic implications of miR-146b expression and its functional role in papillary thyroid carcinoma. J Clin Endocrinol Metab 2013; 98:E196-E205.
57 Li L, Lv B, Chen B, Guan M, Sun Y, Li H, Zhang B, Ding C, He S, Zeng Q: Inhibition of miR-146b expression increases radioiodinesensitivity in poorly differential thyroid carcinoma via positively regulating NIS expression. Biochem Biophys Res Commun 2015; 462:314-321.

58 Menon MP, Khan A: Micro-RNAs in thyroid neoplasms: molecular, diagnostic and therapeutic implications. J Clin Pathol 2009;62: 978-985.

59 Sondermann A, Andreghetto FM, Moulatlet AC, da Silva Victor E, de Castro MG, Nunes FD, Brandao LG, Severino P: MiR-9 and miR21 as prognostic biomarkers for recurrence in papillary thyroid cancer. Clin Exp Metastasis 2015;32:521-530.

60 Chou CK, Chen RF, Chou FF, Chang HW, Chen YJ, Lee YF, Yang KD, Cheng JT, Huang CC, Liu RT: MiR-146b is highly expressed in adult papillary thyroid carcinomas with high risk features including extrathyroidal invasion and the BRAF(v600e) mutation. Thyroid 2010;20:489-494.
61 Boufraqech M, Nilubol N, Zhang L, Gara SK, Sadowski SM, Mehta A, He M, Davis S, Dreiling J, Copland JA, Smallridge RC, Quezado MM, Kebebew E: MiR-30a inhibits LOX expression and anaplastic thyroid cancer progression. Cancer Res 2015;75:367-377.

-62 Yu S, Liu Y, Wang J, Guo Z, Zhang Q, Yu F, Zhang Y, Huang K, Li Y, Song E, Zheng XL, Xiao H: Circulating microRNA profiles as potential biomarkers for diagnosis of papillary thyroid carcinoma. J Clin Endocrinol Metab 2012;97:2084-2092.

63 Zhang Y, Zhong Q, Chen X, Fang J, Huang Z: Diagnostic value of microRNAs in discriminating malignant thyroid nodules from benign ones on fine-needle aspiration samples. Tumour Biol 2014;35:9343-9353.

64 Wei WJ, Shen CT, Song HJ, Qiu ZL, Luo QY: MicroRNAs as a potential tool in the differential diagnosis of thyroid cancer: a systematic review and meta-analysis. Clin Endocrinol (Oxf) 2015. doi:10.1111/cen.12696. 